\title{
ELECTROCARDIOGRAPHIC STUDIES IN CRETINS
}

\author{
BY \\ BERNARD SCHLESINGER AND BERNHARD LANDTMAN*
}

From the Hospital for Sick Children, Great Ormond Street

Received January 5, 1949

There is no direct method of estimating accurately the function of the thyroid gland; so other measures have to be employed in diagnosing thyroid deficiency and in regulating subsequent treatment. Recognition of typical cases of hypothyroidism should not be difficult, but there are borderline cases with slight symptoms that are not so easy to detect. Standard methods of investigation are helpful but have their limitations particularly in young children. At this early age, for instance, accurate estimation of the basal metabolic rate is difficult and therefore unreliable. The blood cholestrol level is usually raised in hypothyroidism, but the test may fail in early or mild forms of the disorder and other conditions may be associated with a high figure.

In searching for additional means of diagnosis attention has been drawn to certain electrocardiographic changes pointing to a disturbed action of the heart. This method of investigation has been used only to a very limited extent in children and pædiatric textbooks contain little or no information on the subject.

\section{Electrocardiograms in Hypothyroidism}

In 1918 Zondek described cardiac disturbances in four adults suffering from hypothyroidism and on the basis of his observations introduced the term " myxœdema heart." The main changes he described were cardiac dilatation, a depressed heart action with a slow pulse rate but normal blood pressure, and the absence of the $\mathbf{P}$ and $\mathrm{T}$ waves in the cardiogram. After thyroid treatment all these abnormalities disappeared. Since then cardiographic investigations of this condition have continued, mostly in myxœdematous adults, but there have also been a few sparse references to children (Cori, 1921; Nobel et al., 1924; Thacher, 1924; Doxiades and Pototzky, 1927; Fournier, 1942; and Sharpey-Shafer, 1943).

The changes generally reported are a low voltage curve with flat $\mathbf{P}$ and flat or negative $\mathbf{T}$ waves. Only two references can be found to alterations in the R-T segments. Chini (1929) reported two myxœdematous children in whom the segment had a convexity, " a tipo coronarico," similar to Pardee's original description in coronary sclerosis. Ohler and Abramson (1934) found similar changes in 4 of 21 adults with hypothyroidism. Prolongation of the P-R interval has been observed in isolated cases (Luten, 1920; Schittenhelm and Eisler, 1927; Ziskin, 1930; Davis, 1931; and Howard, 1929) and a lengthening of the QRS complex in others (Holzman, 1929).

Arrhythmias associated with myxœema seem to be extremely rare. Solitary cases of auricular fibrillation and occasional premature contractions have been described (Ohler and Abramson, 1934; Guerrant and Wood, 1938; Willius and Haines, 1925; Walker, 1933; and Austin, 1937). Bradycardia of sinus origin or with complete heart block and the Stokes-Adams syndrome is sometimes encountered (Willius, 1925). Paroxysmal tachycardia is rarer still (Lisser and Anderson, 1931).

There is a general impression that abnormal electrocardiographic changes in myxœdema disappear in the majority of cases after some weeks thyroid treatment. Flattening of the $P$ and $T$ waves has been noticed after thyroidectomy designed to produce artificial myxœdema in the treatment of congestive heart failure and angina pectoris (Davis et al., 1934) or when thyroidectomy has been carried out too liberally for Graves disease (Hamburger et al., 1929). Animal experiments in support of this have not, however, produced constant results. (Burlage, 1922; Coelho, 1931; and Lueg, 1926).

\section{The Cause of Electrocardiographic Changes IN MYXceDema}

Various explanations have been given of the cause of these changes. An extra-cardial factor such as increased skin resistance has been one popular theory, but there is an increasing belief that an 
alteration in the heart and the conductive mechanism as a result of the hypothyroid state is primarily responsible.

Cutaneous resistance. In order to overcome the possible effect of skin changes in myxœdema, Nobel et al. (1924) used subcutaneous needle electrodes and found an increase in the height of the $\mathbf{P}$ and $\mathbf{T}$ waves compared to the tracing obtained with ordinary standard leads. From this they concluded that the skin and not the heart was primarily at fault.

Other investigators have not been able to confirm these observations and, furthermore, alteration of skin conductivity could hardly account for the prolonged conduction time and other abnormalities observed. The absence of cardiographic changes in skin diseases with extensive cutaneous thickening such as scleroderma and ichthyosis is also of some significance (Hallock, 1934). This has also been our experience in these disorders, in dermatomyositis, and with the widespread œdema of nephrosis.

Sherf and Boyd (1945) using a special electrocardiograph were able to measure the electrical potential directly from the heart. In myxœdema abnormally low potentials were recorded, indicating a lesion of the heart itself.

Pericardial effusion. Some authorities have attributed the cardiographic changes to a pericardial effusion which may arise in myxodema. With thyroid treatment the accumulated fluid disappears and the cardiogram becomes normal, which might be advanced as further proof of the argument (Schnitzer and Gutmann, 1946). But on the whole these effusions are not common and we have never observed them in any child suffering from hypothyroidism.

Nervous factors. A decreased tone of the autonomic nervous system might influence the deflexions, especially of the $\mathrm{T}$ wave, but here again it hardly seems likely that this factor alone could produce the various other abnormalities. (Hamburger et al., 1929; Ohler and Abramson, 1934; v. Pfaundler, 1938.)

Anamia. Secondary anæmia, nearly always present in myxœdema, has been suggested as another possibility (Tung, 1931), but no comparable cardiographic changes have been found in other forms of anæmia of a similar degree of severity.

Myocardial disturbance. In advanced hypothyroidism there may be a reduced cardiac output and enlargement of the heart, which might well modify the shape of the $\mathrm{T}$ wave (Means, 1925; Sherf and Boyd, 1945), but similar cardiographic changes have been found in the early stages without any obvious cardiac failure (Ohler and Abramson, 1934). Myxœdematous swelling of the muscle fibres and connective tissue of the myocardium is the principal post-mortem change discovered, and it is this no doubt that produces the main effect on the cardiogram (Ord, 1880; Schultz, 1921; Ohler and Abramson, 1934; Misske, 1936; LaDue, 1943).*

Arteriosclerosis of the heart is quite common in adult myxœdema and could partly account for the cardiac disturbance (Fishberg, 1924; Christian, 1925; and Feldman, 1936). Coronary disease may thus be responsible for persistent alterations in the $\mathrm{R}-\mathrm{T}$ segment or $\mathrm{T}$ wave deflexions occasionally remaining despite treatment (Ohler and Abramson, 1934; and Fournier, 1942).

\section{Present Investigations}

The present investigation was carried out to ascertain whether electrocardiography can be of any diagnostic assistance in hypothyroidism in infants and young children, particularly when clinical evidence is doubtful. In the course of these studies we were able to place increasing reliance on the abnormal type of tracing discovered, to watch the cardiogram revert to normal under treatment, and ultimately to use it as a control of the optimum amount of thyroid required. Our studies were made on 24 cases, 6 boys and 18 girls, in whom either cretinism or myxœdema had been diagnosed, depending on the age of onset. Both are encountered in childhood, the one dating from birth but only becoming evident round about the third month, and the other appearing later in a previously healthy child. Myxœdema is relatively less common than cretinism; both were found to produce the same cardiographic picture.

The cases fall into two groups:-10 in whom a cardiogram was taken before thyroid treatment was begun and 14 who were already under treatment before this examination was made.

Details of the 10 untreated cases in the first group are summarized in Table I. Seven of them were under the age of one year when first examined. In their appearance all 10 showed typical signs of hypothyroidism with a protruding tongue, dry skin, thickened subcutaneous tissues, an umbilical hernia, hoarse cry, slow snaky movements, and constipation. A delayed bone age was found when radiological examination was carried out.

The electrocardiogram was abnormal in all cases, the most constant finding being a low voltage curve. In addition, changes in the $R-T$ segment were noticed in 8 cases which we came to regard as characteristic. These changes appeared either as a
society of London (1888) and for animal experiments 
TABLE I

Ten Cretins. Electrocardiograms taken before Treatment was Started

\begin{tabular}{|c|c|c|c|c|c|c|c|}
\hline \multicolumn{2}{|c|}{$\begin{array}{l}\text { Case } \\
\text { No. } \\
\text { and } \\
\text { sex }\end{array}$} & Date & $\begin{array}{l}\text { Present } \\
\text { age } \\
\text { (years) }\end{array}$ & $\begin{array}{c}\text { Clinical } \\
\text { signs }\end{array}$ & Main electrocardiographic findings & $\begin{array}{l}\text { Blood } \\
\text { choles- } \\
\text { terol } \\
\text { (mg. \%) }\end{array}$ & $\begin{array}{c}\text { Total daily } \\
\text { thyroid (grains) } \\
\text { showing in- } \\
\text { creasing dosage }\end{array}$ \\
\hline 1 & $\mathbf{F}$ & $\begin{array}{l}12 / 9 / 47 \\
31 / 6 / 48\end{array}$ & $\begin{array}{r}2 / 12 \\
11 / 12\end{array}$ & ++ & $\begin{array}{l}\text { Low voltage; R-T III abnormal } \\
\text { Normal }\end{array}$ & 214 & $\begin{array}{l}0.2 \\
1.0\end{array}$ \\
\hline 2 & $\mathbf{M}$ & $14 / 4 / 48$ & $2 / 12$ & ++ & $\begin{array}{l}\text { Low voltage; R-T I and II abnormal, T I and } \\
\text { II negative }\end{array}$ & 216 & 0.5 \\
\hline 3 & $\mathrm{~F}$ & $\begin{array}{l}17 / 8 / 48 \\
7 / 9 / 48\end{array}$ & $\begin{array}{l}6 / 12 \\
7 / 12\end{array}$ & ++ & $\begin{array}{l}\text { Low voltage; } R-T \text { I and } R-T \text { II abnormal } \\
\text { Q III deep, otherwise normal }\end{array}$ & 134 & $\begin{array}{l}0.75 \\
0.75\end{array}$ \\
\hline 4 & $\mathbf{F}$ & $\begin{array}{l}29 / 10 / 46 \\
15 / 7 / 47 \\
7 / 11 / 47\end{array}$ & $\begin{array}{r}6 / 12 \\
20 / 12\end{array}$ & + & $\begin{array}{l}\text { Low voltage; R-T II abnormal, T I diphasic } \\
\text { Normal; left axis deviation } \\
\text { Normal; left axis deviation }\end{array}$ & $\begin{array}{l}185 \\
160\end{array}$ & $\begin{array}{l}0.2 \\
1.5 \\
1.5\end{array}$ \\
\hline 5 & $\mathbf{M}$ & $\begin{array}{l}25 / 3 / 47 \\
1 / 4 / 47 \\
3 / 6 / 47 \\
21 / 7 / 47 \\
10 / 12 / 47 \\
6 / 4 / 48\end{array}$ & $19 / 12$ & $\begin{array}{l}++ \\
++ \\
+ \\
\pm \\
\pm \\
\pm\end{array}$ & $\begin{array}{l}\text { Low voltage } \\
\text { Same as } 25 / 3 / 47 \\
\text { Q III deep, otherwise normal } \\
\text { Normal } \\
\text { Normal; left axis deviation } \\
\text { Normal }\end{array}$ & $\begin{array}{l}174 \\
176\end{array}$ & $\begin{array}{l}0.25 \\
0.4 \\
0 \cdot 75 \\
1.5 \\
1.5 \\
1.5\end{array}$ \\
\hline 6 & $\mathbf{F}$ & $14 / 4 / 48$ & $10 / 12$ & ++ & Low voltage; $\mathrm{R}-\mathrm{T}$ II and $\mathrm{R}-\mathrm{T}$ III abnormal & 188 & 0.5 \\
\hline 7 & F & $\begin{array}{l}31 / 3 / 47 \\
25 / 5 / 47\end{array}$ & $\begin{array}{l}12 / 12 \\
14 / 12\end{array}$ & ++ & $\begin{array}{l}\text { Low voltage; paroxysmal ectopic rhythm } \\
\text { Normal; left axis deviation }\end{array}$ & 146 & $\begin{array}{l}0.75 \\
1.0\end{array}$ \\
\hline 8 & $\mathbf{M}$ & $\begin{array}{l}14 / 6 / 48 \\
17 / 7 / 48\end{array}$ & 2 & ++ & $\begin{array}{l}\text { Low voltage; R-T II abnormal } \\
\text { Normal }\end{array}$ & 462 & $\begin{array}{l}0.25 \\
1.0\end{array}$ \\
\hline 9 & $\mathbf{M}$ & $\begin{array}{l}22 / 7 / 48 \\
30 / 7 / 48 \\
10 / 8 / 48 \\
19 / 8 / 48 \\
24 / 8 / 48 \\
30 / 8 / 48 \\
6 / 9 / 48 \\
21 / 9 / 48\end{array}$ & 6 & $\begin{array}{l}++ \\
++ \\
++ \\
+ \\
+ \\
+ \\
+ \\
+\end{array}$ & $\begin{array}{l}\text { Low voltage; R-T I and R-T III abnormal } \\
\text { Voltage increased; R-T III abnormal, oc- } \\
\text { casionally S-A block } \\
\text { Normal rhythm. Same as } 30 / 7 / 48 \\
\text { Voltage increased; R-T III abnormal } \\
\text { Same as } 19 / 8 / 48 \\
\text { S-T III almost normal } \\
\text { Same as } 30 / 8 / 48 \\
\text { Same as } 30 / 8 / 48 ; \text { left axis deviation }\end{array}$ & $\begin{array}{l}333 \\
258 \\
190 \\
183 \\
185\end{array}$ & $\begin{array}{l}1.0 \\
1.0 \\
0.5 \\
1.0 \\
0.75 \\
1.0 \\
1.5 \\
2 \cdot 0\end{array}$ \\
\hline 10 & $\mathbf{F}$ & $\begin{array}{l}18 / 3 / 47 \\
8 / 4 / 47 \\
7 / 11 / 47 \\
6 / 1 / 48 \\
3 / 2 / 48 \\
13 / 4 / 48\end{array}$ & $8 \frac{1}{2}$ & $\begin{array}{l}++ \\
++ \\
+ \\
\pm \\
\pm \\
\pm\end{array}$ & $\begin{array}{l}\text { Low voltage; R-T II and R-T III abnormal } \\
\text { Voltage increased; normal } \\
\text { R-T II and R-T III abnormal } \\
T \text { III negative, otherwise as } 7 / 11 / 47 \text {; low } \\
\text { voltage } \\
\text { R-T II and R-T III almost normal } \\
\text { Normal }\end{array}$ & 200 & $\begin{array}{l}1.0 \\
1.0 \\
1.0 \\
1.5 \\
2.0 \\
2 \cdot 5\end{array}$ \\
\hline
\end{tabular}

sloping take off of the segment from the descending part of the initial complex or as a convexity of the segment. A negative $T$ wave in standard leads $I$ and II was recorded in Case 2 only.

Further cardiographic examinations were made during the course of thyroid treatment in 8 cases and the tracings were all found to revert almost or quite to normal in a relatively short time, in Case 3 for instance after 3 weeks treatment. Fig. 1 to 4 taken from Cases 3 and 8 are typical examples of the cardiographic changes and alteration in appearance of the children before and after treatment.

Arrhythmias were observed in two instances: ectopic paroxysmal contractions in the first record of Case 7 and sino-auricular block on one occasion during the course of treatment in Case 9.

Blood cholesterol was estimated in 8 cases before treatment was begun and was found to be above $200 \mathrm{mg}$. per $100 \mathrm{ml}$. in 5 and below this level in 3 cases. 

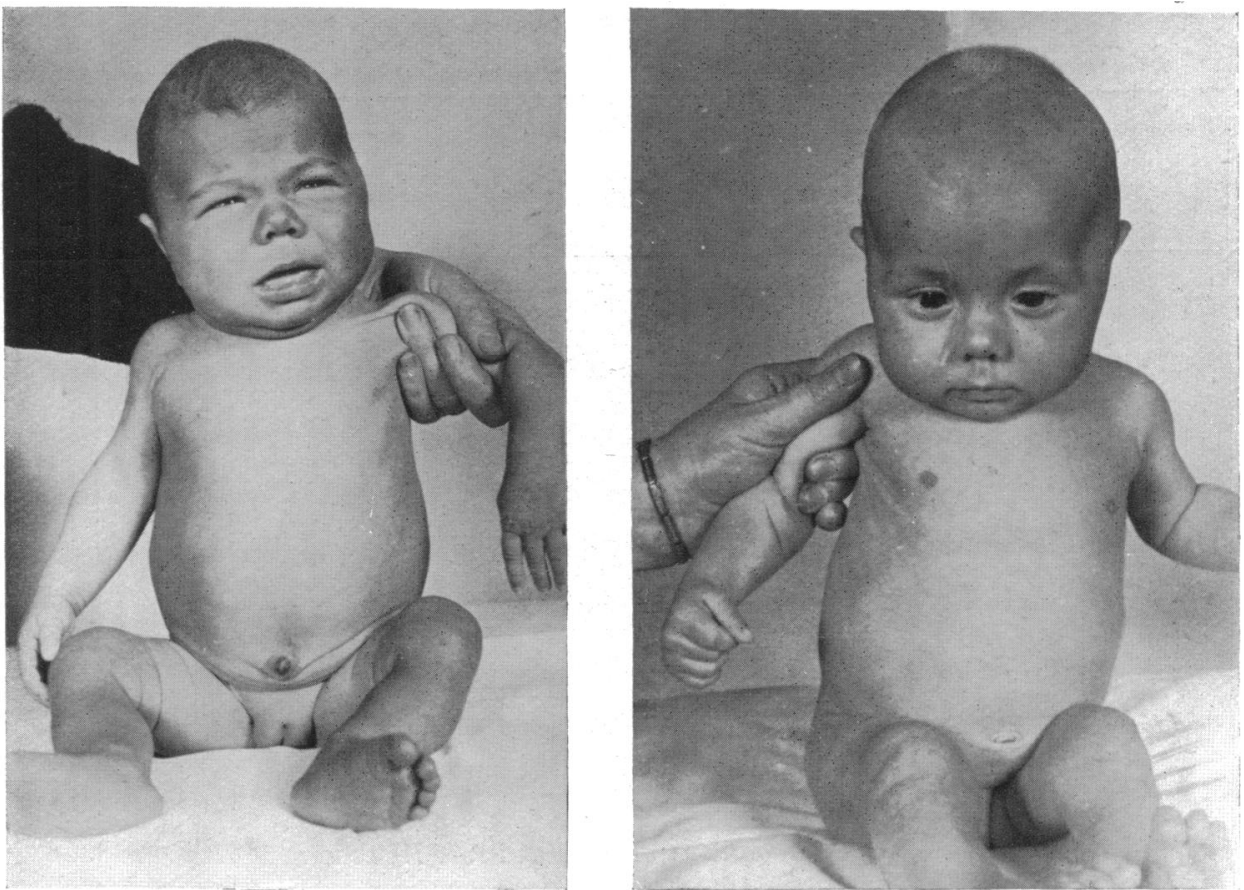

FIG. 1.-Appearance of the child (Case 3) before and after treatment with thyroid (0.75 grains a day) for two months.
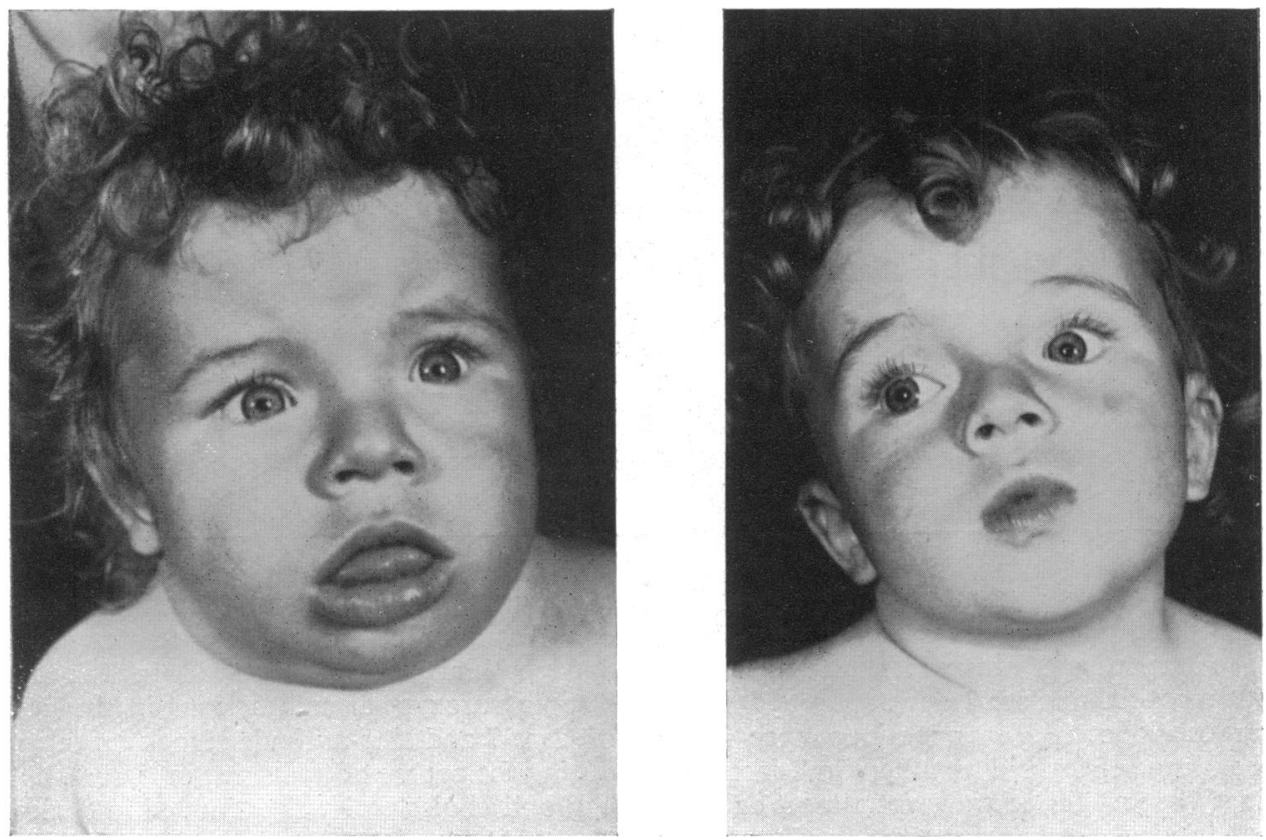

FIG. 2.-Appearance of the child (Case 8) before and after treatment with thyroid for three months. The dose was gradually increased to 1 grain a day. 


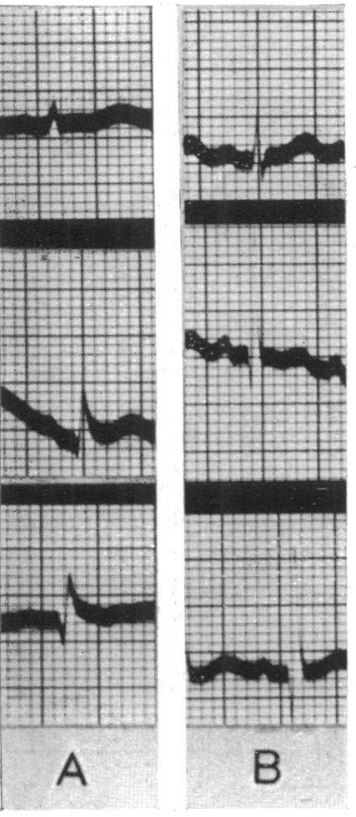

FIG. 3
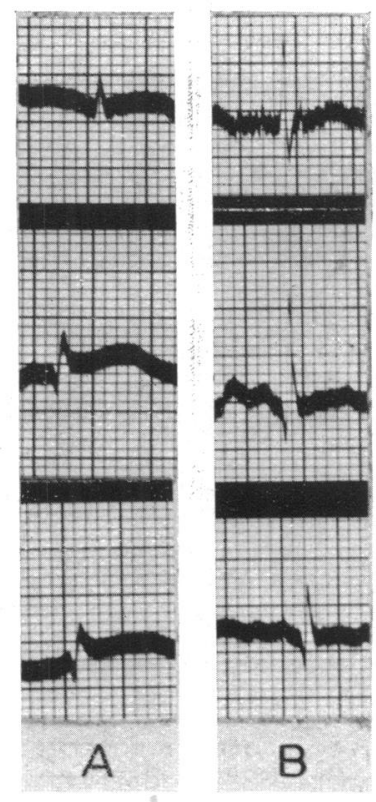

Fig. 4
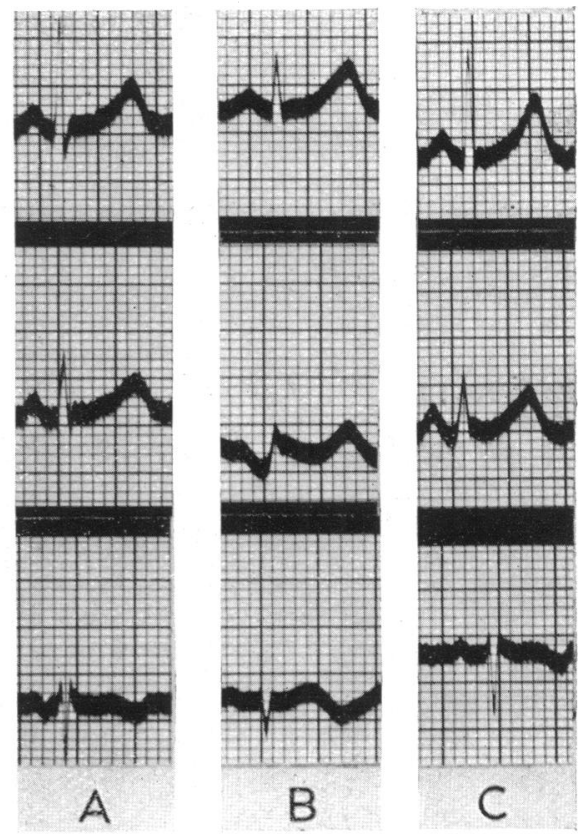

Fig. 5

Fig. 3.-Electrocardiograms of Case 3, aged 6 months. Standard leads. (A) 17/8/48. Before treatment. Low voltage curve and alterations in the S-T segments. (B) 7/9/48. Three weeks after treatment with thyroid (0.75 grain a day). Normal tracing.

Fig. 4.-Electrocardiograms (standard leads) from Case 8, aged 2 years. (A) 14/6/48. Before treatment. Shows the characteristic changes in cretinism. (B) 17/7/48. After treatment with thyroid for one month (dose gradually increased to 1 grain a day). Normal tracing.

Fig. 5.-Tracings illustrating insufficient thyroid dosage. Standard leads from Case 15, aged 10 years. (A) 19/2/47. Normal electrocardiogram after treatment with thyroid (3 grains a day). (B) 2/12/47. Changes appearing after decreasing thyroid to 2.5 grains daily for nine months. (C) 20/4/48. Electrocardiogram has again become normal after increase of thyroid to $3 \cdot 5$ grains a day for two months.

Data concerning 14 cretins in the second group are summarized in Table II. When first seen they all had the characteristic clinical appearance, but treatment had been started before the first cardiogram was taken and in 13 obvious signs of hypothyroidism had disappeared. The cardiogram was normal in 9 cases and in Case 12 the only change, a right axis deviation, was related to a congenital malformation of the heart which was a complicating factor.

\section{InsufFicient Dosage of Thyroid}

An abnormal curve was recorded at one period of our study in 4 children of this group (Cases 11, 15,18 , and 22) and in each instance this was found to be related to inadequate dosage of thyroid.

In Case 11 treatment was begun without delay but in inappropriate amounts, $\mathbf{0} \cdot \mathbf{1}$ grain daily for a month, subsequently reduced to $0 \cdot 1$ grain a week. At the age of 7 months when the child first came under our care she still had a cretinous appearance and the cardiogram showed the typical abnormalities already described. The blood cholesterol level, however, was not raised. Thyroid was then increased to 1.5 grains a day and the cardiogram became normal.

Case 15 was first seen at the age of 17 months, having been on a dose of 3 grains of thyroid a day for 3 months. A cardiogram taken at that time was normal. During the following years her hospital attendance was irregular and thyroid was reduced to 2.5 grains a day. We next saw her at the age of 10 years, normal in appearance, and we only realized that her thyroid level was sub-optimum when cardiograms in succession began to reveal a low voltage curve and changes in the R-T segments. The dose of thyroid was increased to 3.5 grains a day, whereupon the cardiogram again became normal (see Fig. 5A-C).

Case 18 had no obvious clinical symptoms beyond 
TABLE II

Fourteen Cretins. Electrocardiograms taken after Treatment was Started

\begin{tabular}{|c|c|c|c|c|c|c|c|c|}
\hline \multirow{3}{*}{$\begin{array}{l}\text { Case No. } \\
\text { and sex }\end{array}$} & \multirow{3}{*}{\multicolumn{2}{|c|}{$\begin{array}{l}\text { Present } \\
\text { age } \\
\text { yrs. mths. }\end{array}$}} & \multicolumn{4}{|c|}{ Thyroid therapy } & \multirow{3}{*}{ Electrocardiogram } & \multirow{3}{*}{$\begin{array}{l}\text { Blood } \\
\text { cholesterol } \\
\text { (mg. per. } \\
1 \mathrm{CO} \mathrm{ml} . \text { ) }\end{array}$} \\
\hline & & & \multirow{2}{*}{\multicolumn{2}{|c|}{$\begin{array}{l}\text { Begun at } \\
\text { yrs. mths. }\end{array}$}} & \multicolumn{2}{|c|}{ Further Therapy } & & \\
\hline & & & & & Date & $\begin{array}{c}\text { Daily } \\
\text { dose } \\
\text { (grains) }\end{array}$ & & \\
\hline $11 \mathrm{~F}$ & 一 & 7 & - & 3 & $\begin{array}{l}1 / 6 / 47 \\
11 / 9 / 47 \\
10 / 5 / 48\end{array}$ & $\begin{array}{l}0 \cdot 4 \\
1 \cdot 5 \\
2 \cdot 0\end{array}$ & $\begin{array}{l}\text { Low voltage; inverted P III } \\
\text { Low voltage; inverted P III } \\
\text { Normal }\end{array}$ & $\begin{array}{l}132 \\
140\end{array}$ \\
\hline $12 \mathrm{~F}$ & 1 & 6 & - & 6 & $\begin{array}{l}15 / 4 / 48 \\
29 / 7 / 48\end{array}$ & $\begin{array}{l}0 \cdot 5 \\
1 \cdot 0\end{array}$ & $\begin{array}{l}\text { Right axis deviation; extra systoles } \\
\text { Normal rhythm }\end{array}$ & 165 \\
\hline $13 \mathrm{~F}$ & 1 & - & - & 4 & $3 / 7 / 48$ & $0 \cdot 25$ & Normal & 181 \\
\hline $14 \mathrm{M}$ & 1 & 一 & - & 8 & $20 / 1 / 47$ & $1 \cdot 0$ & Normal & 169 \\
\hline $15 \quad F$ & 10 & 6 & 1 & 2 & $\begin{array}{l}15 / 3 / 38 \\
19 / 2 / 47 \\
2 / 12 / 47 \\
9 / 3 / 48 \\
20 / 4 / 48\end{array}$ & $\begin{array}{l}3 \cdot 0 \\
2 \cdot 5 \\
2 \cdot 5 \\
3 \cdot 5 \\
3 \cdot 5\end{array}$ & $\begin{array}{l}\text { Normal; left axis deviation } \\
\text { Inverted P III; left axis deviation } \\
\text { Low voltage; R-T II abnormal } \\
\text { Normal; left axis deviation } \\
\text { Normal; left axis deviation }\end{array}$ & 140 \\
\hline $16 \mathrm{~F}$ & 2 & - & - & 8 & $5 / 1 / 48$ & $1 \cdot 5$ & Normal & 206 \\
\hline $17 \mathrm{~F}$ & 2 & - & 1 & 3 & $8 / 6 / 48$ & $1 \cdot 5$ & Normal & 199 \\
\hline $18 \mathrm{~F}$ & 3 & - & - & 3 & $\begin{array}{l}15 / 6 / 48 \\
27 / 7 / 48\end{array}$ & $\begin{array}{l}1 \cdot 0 \\
2 \cdot 0\end{array}$ & $\begin{array}{l}\text { Low voltage; S-T II and S-T III abnormal } \\
\text { Normal }\end{array}$ & $\begin{array}{l}220 \\
161\end{array}$ \\
\hline $19 \mathrm{~F}$ & 4 & - & - & 4 & $1 / 7 / 47$ & $1 \cdot 0$ & Normal & 167 \\
\hline $20 \mathrm{M}$ & 4 & 2 & 2 & 4 & $2 / 7 / 48$ & $1 \cdot 0$ & Normal & \\
\hline $21 \mathrm{~F}$ & 5 & 3 & - & 9 & $3 / 6 / 47$ & $2 \cdot 0$ & Normal & 196 \\
\hline $22 \mathrm{~F}$ & 6 & 3 & 2 & - & $\begin{array}{l}24 / 5 / 48 \\
28 / 6 / 48\end{array}$ & $\begin{array}{l}2 \cdot 0 \\
2 \cdot 0\end{array}$ & $\begin{array}{l}\text { Low voltage } \\
\text { Normal }\end{array}$ & $\begin{array}{l}460 \\
120\end{array}$ \\
\hline $23 \mathrm{~F}$ & 8 & 4 & - & 7 & $16 / 7 / 48$ & $1 \cdot 5$ & Normal & \\
\hline $24 \mathrm{~F}$ & 11 & 2 & 1 & 5 & $15 / 9 / 47$ & $1 \cdot 5$ & Normal & \\
\hline
\end{tabular}

Only Cases 11 and 12 still showed a slight appearance of cretinism. Case 12 also had evidence of a congenital malformation of the heart. In Case 22 thyroid treatment had been omitted for one month when first investigated.

a slightly increased cholesterol level. Here again electrocardiography betrayed a subthyroid state and after 5 weeks increased dosage abnormalities in the cardiogram and blood cholesterol figure disappeared.

A similar sequence of events occurred in Case 22. Thyroid which was taken in adequate doses for four years had been omitted for one month. The cardiogram then taken showed a low voltage curve. The blood cholesterol was among the highest observed (460 mg. per $100 \mathrm{ml}$.) and yet there were no marked clinical features. The tracing as well as the cholesterol level became normal one month after resuming thyroid treatment at the same dosage.

Case 10 in the first group should also be included as a further example of inadequate therapy regulated by electrocardiographic control (see Fig. 6A-D).

Fuller details of these five cases will be found in Tables I and II. 

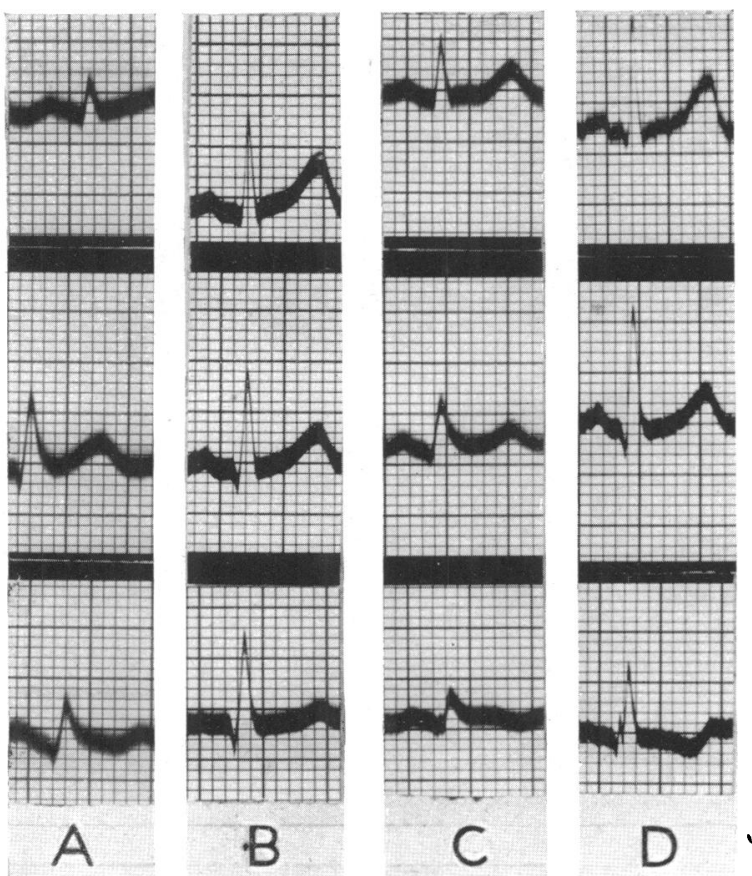

FIG. 6.-Tracings illustrating insufficient thyroid dosage. Standard leads from Case 10, aged 8 years.

(A) $18 / 3 / 47$. Characteristic changes before treatment was started.

(B) $8 / 4 / 47$. Normal tracing after thyroid, 1 grain a day for three weeks.

(C) $7 / 11 / 47$. Seven months later. Thyroid dosage still 1 grain a day. The original changes have reappeared.

(D) 13/4/48. The thyroid dosage has gradually been increased to 2.5 grains a day for five months, and the curve is normal again.

\section{ElECTROCARDIOGRAPHIC ANALYSIS}

The main data are summarized in Table III.

Heart rate. The average heart rate of the 10 untreated cretins was 107 a minute, the lowest figure being 91 a minute (Case 6). In fact no marked bradycardia was observed, but during the course of treatment the heart rate increased somewhat in all these cases. The greatest fluctuation occurred in Case 8 where the rate rose from 100 to 140 a minute after one month's thyroid administration. In the cretins under treatment the mean heart rate was 121 a minute, a figure in the upper limit of normal for this age.

Sinus arrhythmia. The degree of sinus arrhythmia was estimated by the method of Schlomka and Reindell (1936) and was found to be diminished in untreated cretins; in fact the heart beat in this condition, although slower in rate, was found to have the regularity of a " fœtal rhythm."

As a rule sinus arrhythmia become more evident during treatment and in the children who had been taking thyroid for some time before they came under observation it was within normal limits.

Voltage deflexions. Care was taken to standardize the string tension correctly $(1 \mathrm{mv} . / 1 \mathrm{~cm}$.) before each tracing was taken and between each lead. The mean values of the various elements are shown in Table III and it is obvious that QRS and T deflexions are considerably smaller in untreated cretins than in healthy children. A negative T wave in lead III was seen in 8 cases, but by itself we do not regard this as abnormal and Haf kesbring et al.(1937) found it present in $\mathbf{4 0}$ per cent of healthy children.

TABLE III

Low Voltage Electrocardiography Deflexions in Twenty-four Cretins

\begin{tabular}{|c|c|c|c|c|c|c|c|c|c|}
\hline & Standard leads & $\begin{array}{l}\text { No. of } \\
\text { cases }\end{array}$ & $\begin{array}{l}\text { Average } \\
\text { age } \\
\text { (years) }\end{array}$ & $\begin{array}{l}\text { Heart } \\
\text { rate }\end{array}$ & $\underset{\mathrm{mv}}{\mathbf{P}}$ & $\begin{array}{c}\mathrm{Q} \\
\mathrm{mv}\end{array}$ & $\underset{\mathrm{mv}}{\mathbf{R}}$ & $\underset{\mathrm{mv}}{\mathrm{S}}$ & $\underset{\mathrm{mv}}{\mathrm{T}}$ \\
\hline \multirow[t]{2}{*}{ Group I } & Before treatment I & 10 & $2 \frac{1}{12}$ & 107 & $\begin{array}{l}0.04 \\
0 \cdot 10 \\
0 \cdot 05\end{array}$ & $\begin{array}{l}0.05 \\
0 \cdot 12 \\
0 \cdot 15\end{array}$ & $\begin{array}{l}0.34 \\
0.58 \\
0.44\end{array}$ & $\begin{array}{l}0.13 \\
0.03 \\
0.01\end{array}$ & $\begin{array}{l}0 \cdot 14 \\
0 \cdot 17 \\
0 \cdot 05\end{array}$ \\
\hline & $\begin{array}{cl}\text { After treatment } & \text { I } \\
\mathbf{a} & \text { II } \\
& \text { III }\end{array}$ & 8 & $3 \frac{6}{12}$ & 132 & $\begin{array}{l}0 \cdot 11 \\
0 \cdot 15 \\
0 \cdot 04\end{array}$ & $\begin{array}{l}0.04 \\
0 \cdot 13 \\
0.32\end{array}$ & $\begin{array}{l}1 \cdot 01 \\
1 \cdot 10 \\
0 \cdot 65\end{array}$ & $\begin{array}{l}0 \cdot 23 \\
0 \cdot 16 \\
0 \cdot 16\end{array}$ & $\begin{array}{l}0.30 \\
0.31 \\
0.04\end{array}$ \\
\hline Group II & $\begin{array}{ll}\text { After treatment } & \text { I } \\
& \text { II } \\
& \text { III }\end{array}$ & 14 & $2 \frac{6}{12}$ & 121 & $\begin{array}{l}0 \cdot 10 \\
0 \cdot 14 \\
0 \cdot 06\end{array}$ & $\begin{array}{l}0.04 \\
0.07 \\
0.19\end{array}$ & $\begin{array}{l}0.79 \\
0 \cdot 82 \\
0.57\end{array}$ & $\begin{array}{l}0 \cdot 31 \\
0 \cdot 10 \\
0 \cdot 10\end{array}$ & $\begin{array}{l}0.28 \\
0 \cdot 27 \\
0.02\end{array}$ \\
\hline
\end{tabular}

Normal figures for comparison

Average height of $\mathrm{R}$ (standard leads), normal infants: $0.7,0.9$ and $0.7 \mathrm{mv}$; children of 3 years: $1.2,1.5$ and $0.8 \mathrm{mv}$. Normal height of T I and T II, in infants: 0.29 and $0.34 \mathrm{mv}$.; in younger children: 0.37 and $0.35 \mathrm{mv}$. 


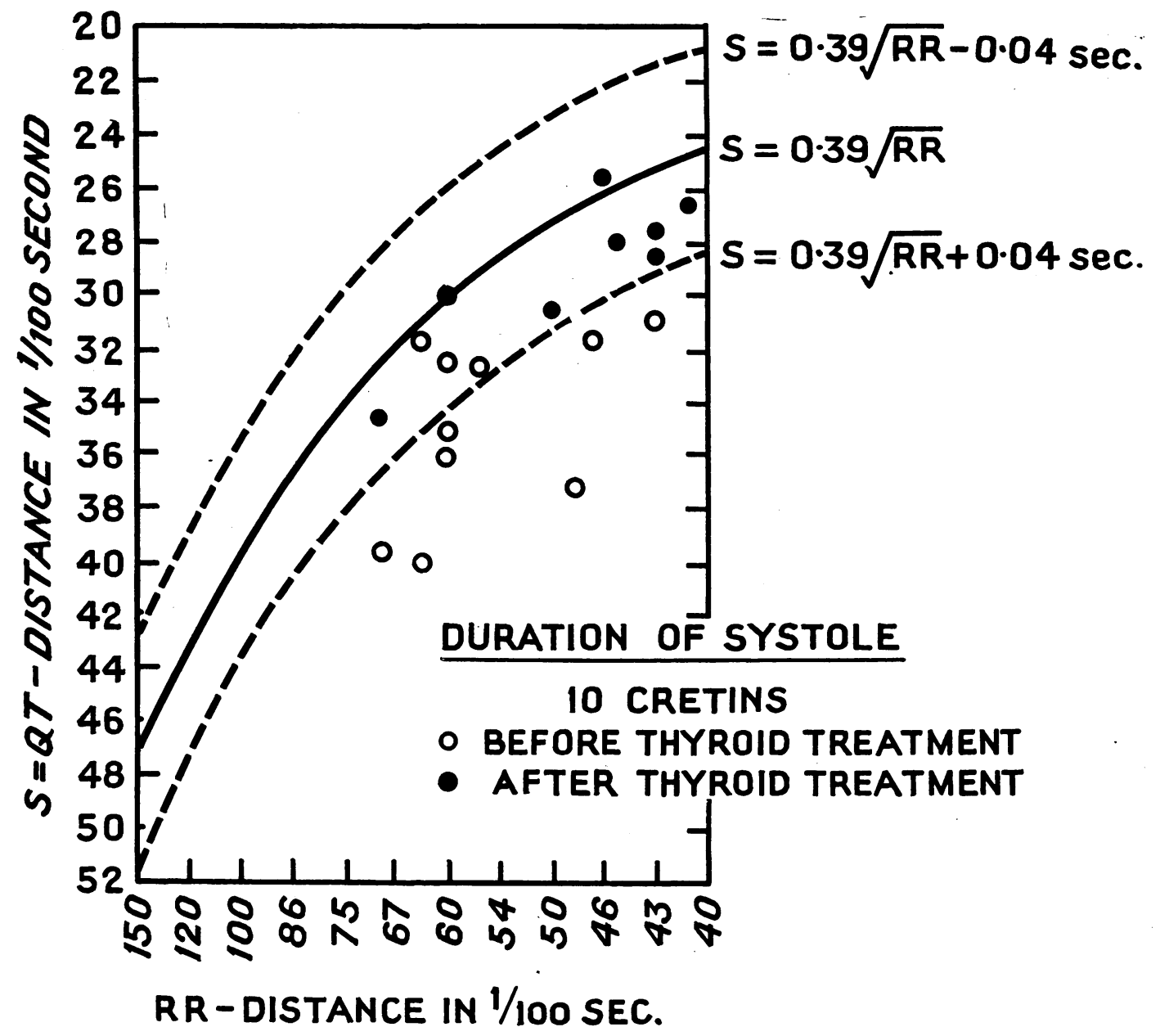

Fig. 7.-The duration of systole in 10 cretins before and after thyroid treatment. It was increased in most of the untreated cretins and became normal after thyroid therapy.

Mean values in normal subjects.

- - - Normal range of variation.

During the course of treatment the low voltage curves disappeared and QRS and $T$ resumed their normal shape and height fairly rapidly. This is also true of the $\mathbf{P}$ waves, particularly in lead $\mathrm{I}$, although it should be realized that wide variations exist in normal children (Burnett and Taylor, 1936). The $\mathbf{Q}$ waves in lead III also tended to increase when thyroid was administered, but this was not seen in the first two leads.

In addition, left axis deviation appeared for a time in 5 cases. In fact it can become permanent and in one girl who has been under our care since infancy on regular and adequate thyroid therapy, left axis deviation is still present at the age of 17 years, although clinically and radiologically the heart appears normal and there is no evidence of left ventricular hypertrophy.

$P-Q$ and $Q-T$ intervals. The $P-Q$ interval usually decreased slightly during treatment, the greatest change being from 0.16 to $0.12 \mathrm{sec}$. (Case 9). The mean values of the $P-Q$ interval did not, however, show any obvious difference in the various groups included in Table III.

The duration of systole was calculated according to a formula suggested by Hegglin and Holzmann (1937). These authors have shown that normal values of the duration of systole (length of $Q-T$ ) plotted against the corresponding frequency of ventricular contractions (RR interval) will lie in an area on a graph limited by two lines and expressed 


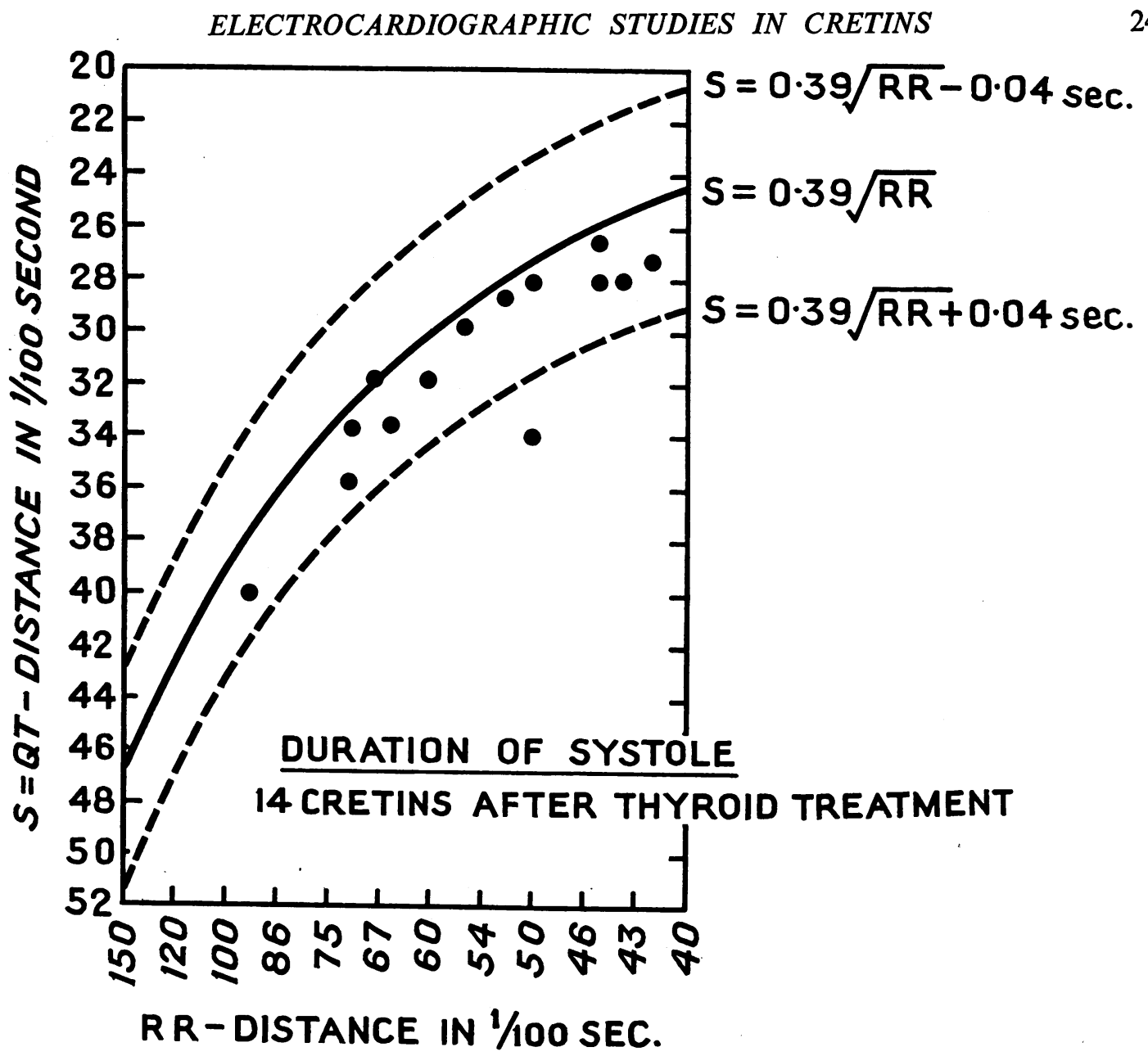

FIG. 8.-The duration of systole in 14 cretins after thyroid treatment. The figure shows that it was normal in all except one case of those cretins who had been treated with thyroid before the electrocardiogram was taken.

\section{Mean values in normal subjects. \\ - - - Normal range of variation.}

as a mathematical formula, $0.39 \sqrt{\text { cycle }} \pm 0.04 \mathrm{sec}$. Using this method the length of systole has been plotted on a graph in the case of 10 cretins before and after treatment (Fig. 7).

The duration of systole was clearly prolonged in 7 cases before treatment and came within normal limits after thyroid had been given. A corresponding calculation was made in the 14 children who had already received treatment before cardiographic records were taken (Fig. 8). The duration of systole here was prolonged in only one instance.

\section{Doubtful Cases of Cretinism}

Occasionally cases arise in which an infant's appearance suggests cretinism but the absence of a completely characteristic clinical picture raises doubt in the diagnosis. In such circumstances we have found the cardiograph a great help.

Two cases can be quoted. An infant was brought to us with a large tongue protruding since birth and an umbilical hernia, but with no other clinical evidence of hypothyroidism. A tentative diagnosis of cretinism had been made which was rather shaken when the blood cholesterol was found to be normal $(115 \mathrm{mg}$. per $100 \mathrm{ml}$.) and X-ray examination showed a normal bone age. A normal cardiogram was the deciding factor; a diagnosis of simple macroglossia was made, no thyroid administered and the child subsequently developed normally with a tongue reduced to the right size.

Another child was originally admitted to the hospital for seborrhœic eczema and gastro-enteritis. 

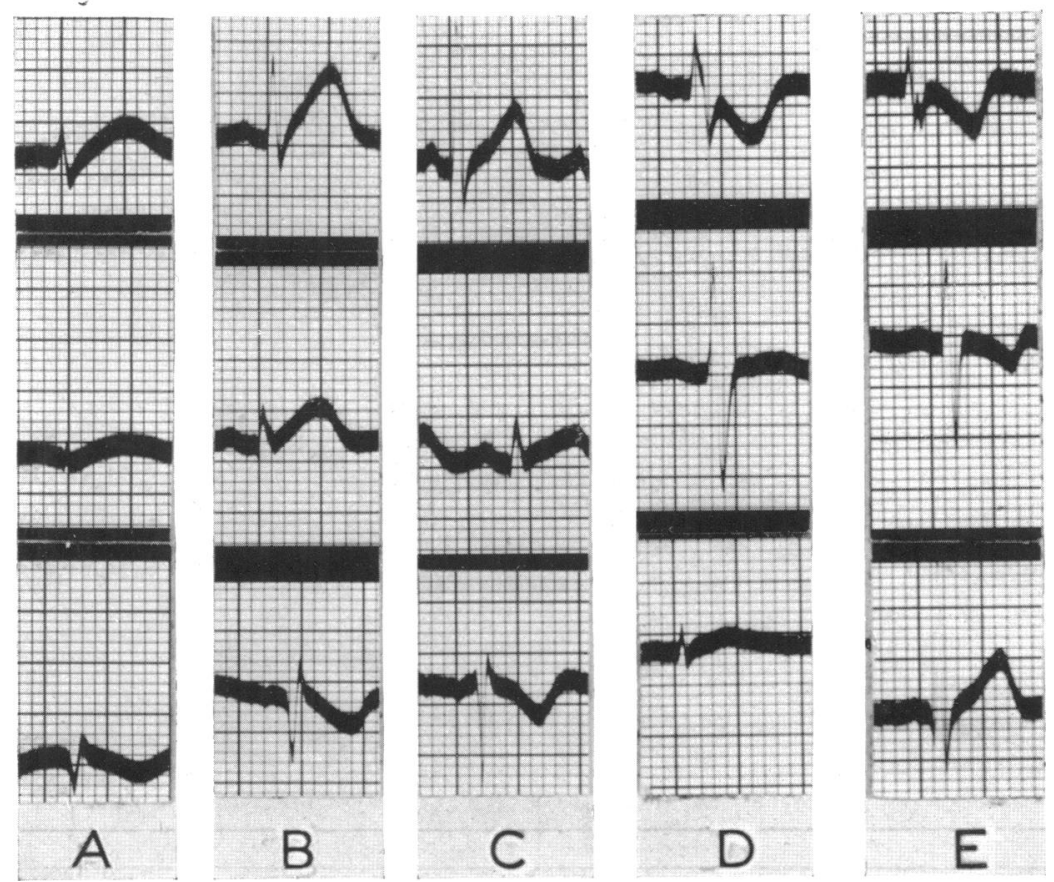

Fig. 9.-Electrocardiograms from Case 9, aged 6 years. (A) 22/7/48. Standard leads taken before treatment show the characteristic changes of cretinism. (B) $24 / 8 / 48$. One month after treatment with thyroid (1 grain a day). Voltage increased, abnormalities in $R-T$ segments disappearing. (C) 21/9/48. One month later, dosage of thyroid has been increased to 2 grains a day. Left axis deviation, otherwise almost normal tracing. (D) 30/7/48. Three unipolar chest leads taken one week after beginning of the treatment with thyroid (1 grain a day). Abnormal $\mathrm{S}-\mathrm{T}$ segments in $\mathrm{V} 1$; flat upright $\mathrm{T}$ in V 2 and low voltage curve in V 5 . (E) 21/9/48. Three unipolar chest leads after two months treatment with thyroid (dosage gradually increased to 2 grains a day). S-T segment deviations in V 1 less marked; inverted $\mathrm{T}$ wave in $\mathrm{V} 2$ and voltage increased in $\mathrm{V} 5$.

The general appearance at that time also suggested a slight degree of hypothyroidism, a diagnosis also favoured by an increased blood cholesterol level. Thyroid therapy was given for four months, but when two early cardiograms in succession were found to be quite normal, treatment was stopped with no detrimental effect on the child's subsequent healthy development.

\section{Discussion}

These studies have shown that characteristic changes in the electrocardiogram occur in untreated cretins which are reversible in a comparatively short time on thyroid administration. If the dosage is interrupted or becomes inadequate cardiographic abnormalities reappear. Alterations in cutaneous resistance are probably partly responsible for the cardiographic changes because the voltage of the deflexions is considerably increased by the use of subcutaneous leads, a phenomenon we have also observed in normal subjects. Such myxœdematous skin infiltration can, however, only play a minor part. Changes in the R-T segment, which are also present in unipolar chest leads, and prolongation of systole could not be explained on this basis (see Fig. 9A-E).

Pericardial effusion, occurring at times in adult myxœdema, has not been encountered by us in cretins, and arteriosclerosis of the coronary vessels has not had time to develop at this age and cannot therefore be responsible for the $R-T$ changes. Anæmia is also not a contributory factor; it is never profound and more than once the cardiogram was observed to return to normal during treatment without any corresponding improvement of the blood count. Nervous factors may have some effect on the cardiac action in cretins and the low degree of sinus arrhythmia present may be partly 
an indication of this (Landtman, 1947), but from all the evidence direct involvement of the myocardium seems to be the most likely cause of the main cardiographic changes. Myxœdematous infiltration causes the heart muscle to swell and is likely to interfere with its action. Thyroid treatment rapidly restores the heart to normal and in this way the pathology is somewhat reminiscent of the heart in beriberi which quite rapidly becomes normal when appropriate treatment is given without delay (Weiss and Wilkins, 1937).

\section{SUMmaRY}

Studies of the electrocardiogram were carried out on 24 infants or young children with hypothyroidism and the changes found are described. Evidence is brought forward of the value of this method of investigation in regulating the dosage of thyroid required and in the diagnosis of doubtful cases. The possible cause of these changes is discussed and evidence is produced pointing to direct myocardial involvement.

We are grateful to a number of our colleagues for placing their cases at our disposal and to Mr. Derek Martin and Mr. A. H. Prickett for their patient co-operation and technical assistance.

Thanks are due to The British Council for the facilities granted to one of us (B.L.) in his studies in this country and to The Academy of Finland for a scholarship granted to him.

\section{REFERENCES}

Austin, U. T. (1937). Illinois med. J., 72, 417.

Burlage, S. R. (1922). Proc. Soc. exp. Biol., 19, 425.

Burnett, C. T., and Taylor, E. L. (1936). Amer. Heart J., 11, 185 .

Chini, V. (1929). Cuore Circul., 13, 32.

Christian, H. A. (1925). Rhode Island med. J., 8, 109.

Coelho, E. (1931). Ann. Med., 30, 272.

Cori, G. (1921). Z. ges. exp. Med., 25, 150.

Davis, J. C. (1931). Ann. intern. Med., 4, 733.

Davis, D., Weinstein, A. A., Roseman, J. E. F., and Blumgart, H. L. (1934), Amer. Heart J., 10, 17.

Doxiades, L., and Pototzky, C. (1927). Klin. Wschr., $6,1326$.

Feldman, L. (1936). Illinois med. J., 70, 58.

Fishberg, A. M. (1924). J. Amer. med. Ass., 82, 463.

Fournier, J. C. M. (1942). Proc. Mayo. Clin, 17, 212.

Goldberg, S. (1927). Quart. J. exp. Physiol., 17, 15.

Guerrant, J. L., and Wood, J. E. (1938). Virginia med. Mon., 65, 488.

Hafkesbring, E., Drawe, C., and Ashman, R. (1937). Amer. J. Dis. Child., 53, 1457.

Hallock, P. (1934). Amer. Heart J., 9, 196.

Hamburger, W. W., Lev, M. W., Priest, W. S., and Howard, H. C. (1929). Arch. intern. Med., $43,35$.

Hegglin, R., and Holzmann, M. (1937). Z. Klin. Med., 132, 1 .

Holzman, J. E. (1929). Amer. Heart J., 4, 351.

Howard, H. C. (1929). Arch. intern. Med., 43, 35.

LaDue, J. S. (1943). Ibid., 18, 332.

Landtman, B. (1947). Acta paediat. Stockh., Suppl. 1, Vol. 34 .

Lisser, H., and Anderson, E. M. (1931). Endocrinology, 15,365 .
Lueg, W. (1926a). Z. Klin. Med., 104, 337. (1926b). Arch. ges. Physiol., 212, 649.

Luten, D. (1920). J. Missouri med. Ass., 25, 73.

Mannheimer, E. (1940). Acta paediatr. Stockh., Suppl. 2, Vol. 28.

Means, J. H. (1925). Endocrinology, 9, 3.

Misske, B. (1936). Z. Kreisl. Forsch., 28, 601.

Nadrai, A. (1938). $\quad Z$. Kinderheilk., 60, 285.

Nobel, E., Rosenblüth, A., and Samet, B. (1924). Z. Zes. exp. Med., 43, 332.

Ohler, W. R., and Abramson, J. (1934). Arch. intern. Med., 53, 165.

Ord, W. M. (1880). Trans. clin. Soc., London, 13, 15.

v. Pfaundler, M. (1938). Lehrbuch der Kinderheilkunde, Edited by E. Feer, Jena.

Schittenhelm, A., and Eisler, B. (1927). Klin. Wschr., 6, 1935.

Schlomka, G., and Reindell, H. (1936). Z. Kreisl. Forsch., 28, 473.

Schnitzer, R., and Gutmann, D. (1946). Brit. Heart J., $8,25$.

Schultz, A. (1921). Virchows Arch., 232, 362.

Sharpey-Shafer, E. P. (1943). Brit. Heart J., 5, 85.

Sherf, D., and Boyd, L. J. (1945). Clinical Electrocardiography, London.

Thacher, C. (1924). Amer. J. Dis. Child., 28, 25.

Transactions Clinical Soc. London (1888). Supl. 21.

Tung, C. L. (1931). Amer. Heart J., 6, 734.

Walker, J. E. (1933). J. Amer. med. Ass., 100, 1025.

Weiss, S., and Wilkins, R. (1937). Ann. intern. Med., 21, 104.

Willius, F. A., and Haines, S. R. (1925). Canad. med. Ass. J., 14, 1072.

Ziskin, T. (1930). U.S. Veterans' Bur. Med. Bull., 6, 24.

Zondek, H. (1918). Munch. med. Wschr., 65, 1180.

\section{References to Electrocardiographic Changes in Myxcedematous Adults}

Allen, W. H. (1937). J. Amer. med. Ass., 108, 2037.

Ayman, D., Rosenblum, H., and Falcon-Lesses, M. (1932). Ibid., 98, 1721 .

Baratz, J. J., and Bronstein, I. P. (1942). Amer. J. Dis. Child., 64, 471.
Benestad, G. (1937). Nor. med. Tdskr., 14, 1741.

Bronstein, I. P., and Baratz, J. J. (1936). Amer. J. Dis. Child., 52, 128.

Campbell, M., and Suzman, S. S. (1934). Guy's Hospital Report, 84, 281. 


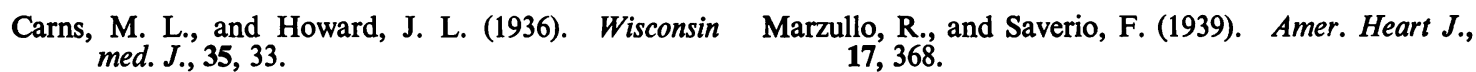

Christiansen, T., and Rosling, E. (1938). Acta path. microbiol. Scand., Suppl. 37, 123.

Evans, C. (1937). Lancet, 2, 1300.

Fahr, G. (1925). J. Amer. med. Ass., 84, 345.

- (1933). Amer. Heart J., 8, 91.

Freeman, E. B. (1934). Ann. intern. Med., 7, 1070.

Higgins, W. H. (1936). Amer. J. med. Sci.; 191, 80.

Howell, L. P. (1945). Proc. Mayo. Clin., 20, 250.

Hurxthal, L. M. (1935). New Engl. J. Med., 213, 264.

Introna, F. (1937). Cuore Circul, 26, 649.

Lerman, J., Clark, R. J., and Means, J. H. (1933). Ann. intern. Med., 6, 1251.

Means, J. H. (1933). New Engl. J. Med., 208, 541.

-, White, P. D., and Krantz, C. I. (1926). Boston med. surg. J., 195, 455.

Reid, W. D., and Kenway, F. L. (1929). Endocrinology, 13, 191.

Thacher, C., and White, P. D. (1926). Amer. J. med. Sci., $171,61$.

White, P. D., and Aub, J. C. (1918). Arch. intern. Med., 22, 766.

Zondek, H. (1919). Munch. med. Wschr., 66, 681. (1919). Ther. Gegenw., 60, 631. 